$1-1-1993$

\title{
Killing Brown Softly: The Subtle Undermining of Effective Desegregation in Freeman v. Pitts
}

Bradley W. Joondeph

Santa Clara University School of Law, bjoondeph@scu.edu

Follow this and additional works at: http://digitalcommons.law.scu.edu/facpubs

\section{Recommended Citation}

46 Stan. L. Rev. 147

This Article is brought to you for free and open access by the Faculty Scholarship at Santa Clara Law Digital Commons. It has been accepted for inclusion in Faculty Publications by an authorized administrator of Santa Clara Law Digital Commons. For more information, please contact sculawlibrarian@gmail.com. 


\title{
NOTES
}

\section{Killing Brown Softly: The Subtle Undermining of Effective Desegregation}

\author{
in Freeman v. Pitts
}

\author{
Bradley W. Joondeph*
}

\begin{abstract}
Uncertainty continues to surround the issue of what steps a racially segregated school district must take to comply with the Equal Protection Clause of Fourteenth Amendment, as interpreted by Brown v. Board of Education. The Supreme Court's recent decision in Freeman v. Pitts expanded district courts' discretion in releasing school districts from court-ordered desegregation plans, allowing courts to withdraw supervision incrementally from individual areas of school district operations. In this note, Bradley Joondeph argues that such incremental withdrawal of supervision allows school districts to take measures that have a resegregatory effect on areas in which compliance has been achieved, and may therefore undermine the ultimate goal of court-ordered desegregation plans: eliminating the racial identifiability of formerly segregated schools. Mr. Joondeph suggests the Court instead should have endorsed an alternative system of "prophylactic" supervision that would maintain court supervision over all areas of school operations until each area has been successfully desegregated.
\end{abstract}

\section{INTRODUCTION}

In Brown v. Board of Education, ${ }^{1}$ the Supreme Court held that racial segregation of public schools violates the Equal Protection Clause of the Fourteenth Amendment, ${ }^{2}$ concluding that "in the field of public education the doctrine of 'separate but equal' has no place."3 While the central holding of Brown is clear, the federal courts continue to struggle to define precisely what segregated

* Third-year student, Stanford Law School. This note is dedicated to the memories of Dean Charles Hamilton Houston and Justice Thurgood Marshall, whose contributions to the struggle for equal justice under law are unparalleled in this country's history. I wish to thank Professor Gerald Gunther, Andrew Berke, Chris Guthrie, Srija Srinivasan, and my parents, Donald and Priscilla Joondeph, for their generous help and support. I also wish to thank the editors at the Stanford Law Review for their dedication and thoughtful contributions.

1. 347 U.S. 483 (1954) (Brown I).

2. Id. at 495 .

3. Id. 
school districts must do to comply with the Equal Protection Clause, ${ }^{4}$ and when district courts should return control to local authorities. ${ }^{5}$

The Constitution forbids segregation in public schools stemming from intentional discrimination, often referred to as de jure segregation. ${ }^{6}$ In contrast, de facto segregation-resulting from factors other than school officials' purposeful actions-raises no constitutional concerns. ${ }^{7}$ If a school district is found to be operating a de jure segregated school system, it must "do more than

4. The Court uses the term "unitary status" to describe the point at which a school district has completely dismantled its previously "dual" system, thereby satisfying its Constitutional requirements. See, e.g., Green v. County Sch. Bd., 391 U.S. 430, 435-36. As the Court recently explained in Board of Education v. Dowell, 498 U.S. 237 (1991), "[c]ourts have used the terms 'dual' to denote a school system which has engaged in intentional segregation of students by race, and 'unitary' to describe a school system which has been brought into compliance with the command of the Constitution." Id. at 246.

Although virtually every desegregation decision invokes the term "unitary," courts have had difficulty defining when school systems achieve unitary status. See Freeman v. Pitts, 112 S. Ct. 1430, 144344 (1992) (stating that "the term 'unitary' is not a precise concept" and "does not have fixed meaning or content"); Kevin Brown, Termination of Public School Desegregation: Determination of Unitary Status Based on the Elimination of Invidious Value Inculcation, 58 GEO. WASH. L. REv. 1105,1107 n.7 (1990) (noting that " $[t]$ here is a considerable amount of confusion about the terminology in this area"); Martha M. McCarthy, Elusive "Unitary Status," 69 Educ. L. Rep. (West) 9 (1991) (arguing that unitary status remains subject to multiple interpretations); Note, Allocating the Burden of Proof after a Finding of Unitariness in School Desegregation Litigation, 100 HARV. L. REV. 653, 662 (1987) [hereinafter Allocating the Burden of Proof] (observing that the Court has never "produced a single, comprehensive statement defining unitariness").

5. See, e.g., Freeman, $112 \mathrm{~S}$. Ct. at $1444-45$ (allowing courts to commence partial withdrawal of supervision before school districts have achieved full compliance with the Fourteenth Amendment); Dowell, 498 U.S. 249-50 (stating that a district court should decide whether to return control to local officials after considering "whether the [officials] had complied in good faith with the desegregation decree . . . and whether the vestiges of past discrimination had been eliminated to the extent practicable"); United States v. Overton, 834 F.2d 1171, 1175 (5th Cir. 1987) (allowing a district court to release a school district from court control "when it eliminates the vestiges of a segregated system and achieves a true unitary system"); Morgan v. Nucci, 831 F.2d 313, 330 (1st Cir. 1987) (stating that it was reasonable for a district court to retain control over a school system "where the school defendants had yet to achieve compliance with . . . part of the original desegregation plan"); Riddick v. School Bd. of Norfolk, 784 F.2d 521, 535 (4th Cir.) ("Once ... a remedy is fashioned, the district court retains jurisdiction until it is clear the that unlawful segregation has been completely eliminated. But once the goal of a unitary school system is achieved, the district court's role ends."), cert. denied, 479 U.S. 938 (1986).

6. See, e.g., Columbus Bd. of Educ. v. Penick, 443 U.S. 449, 458 (1979) (stating that "[p]roof of purposeful and effective maintenance of a body of separate black schools in a substantial part of the system itself is prima facie proof of a dual school system"); Arlington Heights v. Metropolitan Hous. Corp., 429 U.S. 252, 265 (1977) (stating that "'[p]roof of racially discriminatory intent or purpose is required to show a violation of the Equal Protection Clause").

7. See, e.g., Freeman, 112 S. Ct. at 1447 (stating that school systems have no obligation to desegregate "when the [racial] imbalance is attributable neither to the prior de jure system nor to a later violation by the school district but rather to independent demographic forces"); Milliken v. Bradley, 433 U.S. 267, 280 n.14 (1977) (Milliken II) (noting that "the Court has consistently held that the Constitution is not violated by racial imbalance in the schools, without more"); Washington v. Davis, 426 U.S. 229,240 (1976) (remarking that the existence of "both predominantly black and predominantly white schools in a community is not alone violative of the Equal Protection Clause"); Swann v. CharlotteMecklenburg Bd. of Educ., 402 U.S. 1, 17-18 (1971) (emphasizing that courts may not act "where racial imbalance exists in the schools but with no showing that this was brought about by discriminatory action of state authorities"'); see also James S. Liebman, Implementing Brown in the Nineties: Political Reconstruction, Liberal Recollection, and Litigatively Enforced Legislative Reform, 76 VA. L. REv. 349, 354 (1990) (stating that the Court's desegregation decisions during the 1970s made clear "that racial separation itself, even when coupled with vast disparities in economic input and educational outcome, did not suffice" to justify judicial intervention). 
abandon its prior discriminatory purpose." 8 Rather, the segregated school district is charged with "the affirmative duty to take all steps necessary to eliminate the vestiges of the unconstitutional de jure system."' Not until the school district has purged itself entirely of the segregated, "dual" system and replaced it with a nondiscriminatory "unitary" system of education is it fully desegregated for purposes of the Fourteenth Amendment. ${ }^{10}$

The process of court-ordered desegregation begins with a finding that discrimination by school officials has led to segregation in a school district. ${ }^{11}$ Upon such a finding, the district court usually orders the school district to come forward with a comprehensive plan to desegregate its schools. ${ }^{12}$ If the court finds the school district's plan unsatisfactory, the court must devise such a scheme itself. ${ }^{13}$ In either case, the school system is legally bound by the desegregation plan, ${ }^{14}$ and the district court retains jurisdiction over the case until the school district is fully desegregated. ${ }^{15}$ Once the school district believes it has

8. Dayton Bd. of Educ. v. Brinkman, 443 U.S. 526, 538 (1979) (Dayton II).

9. Freeman, 112 S. Ct. at 1443; see also Swann, 402 U.S. at 15 (stating that "[t]he objective today remains to eliminate from the public schools all vestiges of state-imposed segregation"); Green v. County Sch. Bd., 391 U.S. 430, 437-38 (1968) (stating that nonunitary school districts are "clearly charged with the affirmative duty to take whatever steps might be necessary to convert to a unitary system in which racial discrimination would be eliminated root and branch"); Brown v. Board of Educ., 892 F.2d 851, 861 (10th Cir. 1989) (describing the School Board's obligation "to act affirmatively, not merely to act neutrally"), vacated, 112 S. Ct. 1657 (1992), reinstated, 978 F.2d 585 (10th Cir. 1992), cert. denied, 113 S. Ct. 2994 (1993), (Brown III); J. HARVIE WILKINSON III, FROM BROWN TO BaKXEE: The SUPREMe Court and School Integration: 1954-1978, at 116 (1979) (discussing how Green "removed, at long last, from black children the onus of achieving integration and threw it squarelyaffirmatively - onto the backs of local school boards"); Allocating the Burden of Proof, supra note 4, at 653 (stating that a finding of intentional segregation "places the school board under an affirmative duty to change the system from a dual to a 'unitary' one").

10. Green, 391 U.S. at 439 (holding that de jure segregated school systems are under the obligation to affirmatively desegregate "until it is clear that state-imposed segregation has been completely removed"); see also Columbus Bd. of Educ. v. Penick, 443 U.S. 449, 461 (1979) (explaining that the school system was in violation of the Constitution because of "its failure to eliminate the consequences of its past intentionally segregative policies").

11. See, e.g., Board of Educ. v. Dowell, 498 U.S. 237, 240 (1991) (initiating court supervision after plaintiffs demonstrated that "Oklahoma City was operating a dual school system-one that was intentionally segregated by race").

12. Green, 391 U.S. at 439 (holding that an offending school board must "come forward with a plan that promises realistically to work, and promises realistically to work now"); see also Columbus, 443 U.S. at 453 (ordering school district to submit "systemwide desegregation plan" after the district court found that segregation of the district's schools " 'directly resulted from [the Board's] intentional segregative acts and omissions' ") (quoting Penick v. Columbus Bd. of Educ., 429 F. Supp. 229, 259 (S.D. Ohio 1977)).

13. See 3 Ronald D. Rotunda \& John E. Novak, Treatise on Constimutional law \$ 18.9(a)(1) (2d ed. 1992); see also Swann, 402 U.S. at 15 ("'T]f school authorities fail in their affirmative obligations," then "the scope of a district court's equitable powers to remedy past wrongs is broad, for breadth and flexibility are inherent in equitable remedies.").

14. See, e.g., Pasadena Bd. of Educ. v. Spangler, 427 U.S. 424, 438 (1976) (explaining that the school system's violation of its desegregation order "can result in punishment for contempt in the form of either a fine or imprisonment"').

15. The role of district courts in monitoring compliance with Brown was set by the Court in Brown II. Brown v. Board of Educ., 349 U.S. 294, 299-301 (1955) (Brown II). As Laurence Tribe notes, " 'Because of their proximity to local conditions and the possible need for further hearings,' the federal district courts were delegated primary responsibility to supervise the 'transition to a system of public education freed of racial discrimination." "LaURence $H$. TRIBE, American Constrtumional LAW § 16-18, at 1488-89 (2d ed. 1988) (quoting Brown II, 349 U.S. at 299). 
fulfilled its obligations under the court-ordered plan, it may petition the court for a declaration that the school district has achieved "unitary status," and for dissolution of the court's desegregation order. ${ }^{16}$ If the court finds that the school district has successfully desegregated, it will return control of the system to local authorities. ${ }^{17}$ Once declared unitary, the school district's constitutional obligations are the same as those of any other nonsegregated school system. ${ }^{18}$

In Freeman $v$. Pitts, ${ }^{19}$ the Supreme Court expanded the discretion district courts may exercise in releasing school districts from court-ordered desegregation plans. Specifically, Freeman held that district courts may withdraw their supervision over formerly segregated school systems incrementally. ${ }^{20}$ Writing for the Court, Justice Kennedy explained that in cases of "partial compliance"- where the school district has achieved unitary status in some but not all areas of its operations-the court may return control of the successfully desegregated areas to school officials while retaining supervision over areas that remain segregated.21

This note explores the legal basis for the Court's holding in Freeman and discusses the implications of its approval of incremental withdrawal of judicial supervision in desegregation litigation. Part I examines the Supreme Court's analysis in Freeman. It contends that the Court's broad reading of Pasadena Board of Education v. Spangler ${ }^{22}$ ignores the important conceptual distinction between mandating that a school district take affirmative steps to desegregate and requiring the district to refrain from taking actions that have de facto segregatory effects. Part II examines the ways in which Freeman's approval of incremental withdrawal redefines unitary status. Part III discusses how Freeman may permit nonunitary school districts to incrementally resegregate their schools and illustrates how such incremental resegregation can lead to the release from judicial supervision of formerly segregated school districts which have yet to eliminate the racial identifiability of their schools. Finally, Part IV suggests that the Court should have required district courts to retain supervision over all aspects of school systems that retain vestiges of de jure segregation in order to prevent such districts from taking steps that may exacerbate segregation in their schools. Part IV also discusses an important issue left unresolved by Freeman: what showing a plaintiff must make in order for a court to reassert control over previously released areas of a partially compliant school system. It contends that a plaintiff should only have to prove that district court

16. See, e.g., Spangler, 427 U.S. at 428-29.

17. Allocating the Burden of Proof, supra note 4, at 661-62 ("Once a formerly dual school system is declared unitary, and the district court has terminated any injunctions, that court relinquishes its power to evaluate and aiter educational plans. The primary consequence of unitariness is, then, that the school board regains ongoing control over the decisionmaking process in the system.").

18. Board of Educ. v. Dowell, 498 U.S. 237, 250 (1991); David S. Tatel, Desegregation Versus School Reform: Resolving the Conflict, 4 STAN. L. \& PoL'Y REv. 61, 63 (1992) (commenting that, after the supervising court has declared the school district "unitary," the system's "legal obligations are no different from any other school district").

19. 112 S. Ct. 1430 (1992).

20. Id. at $1444-45$.

21. Id. at $1445-46$.

22. 427 U.S. 424 (1976). 
supervision is "reasonably necessary" for the school system to achieve unitary status.

\section{Freeman, SPANGLER, AND the Duty to Take Affirmative Steps to DESEGREGATE}

\section{A. The Holding in Freeman}

In 1954, the year the Supreme Court decided Brown, schools in DeKalb County, Georgia, were segregated by law. ${ }^{23}$ Like many southern school districts, the DeKalb County School System (DCSS) resisted the Court's mandate to desegregate. ${ }^{24}$ DCSS did not take any steps to dismantle its dual system until the 1966-67 school year, 25 when DCSS implemented a "freedom of choice" plan designed to enable all DCSS students to attend the school of their choice within the system. ${ }^{26}$ In practice, only a modest number of AfricanAmerican students took advantage of the program, and DCSS's schools remained almost completely segregated. ${ }^{27}$

In 1968, the Supreme Court decided in Green v. County School Board ${ }^{28}$ that the implementation of a "freedom of choice" plan was not enough by itself to satisfy a school district's obligation to desegregate. ${ }^{29}$ Two months later, a group of African-American DeKalb residents initiated a class action suit against DCSS seeking that it dismantle its discriminatory system. ${ }^{30}$ In response, DCSS, in conjunction with the Department of Health, Education, and Welfare (HEW), devised a comprehensive plan to desegregate the DCSS schools. ${ }^{31}$ The district court approved the plan in 1969.32 From 1969 to 1986, while DCSS remained under judicial supervision, DeKalb County underwent dramatic demographic changes, such that the proportion of African-American

23. Freeman, $112 \mathrm{~S}$. Ct. at 1436 . Whether district courts should be permitted to withdraw supervision over school districts incrementally in desegregation litigation was not the only issue contested in Freeman. Significant portions of the briefs and the opinion considered whether the existing racial imbalance in student assignments was a "vestige" of the school district's past discrimination. See id. at 1449-50; Brief of Petitioners at 4-5, Freeman (No. 89-1290); Respondents' Brief at 47, Freeman (No. 89-1290). This debate focused on the school district's record of student assignment, with respondents contending that the district had never effectively desegregated or achieved unitary status. Id. Dramatic intervening demographic shifts in DeKalb County made determining whether the original constitutional violation caused the present segregation of students quite difficult. Freeman, $112 \mathrm{~S}$. Ct. at 1437-39.

24. Freeman, 112 S. Ct. at 1436. DeKalb County is located in suburban Atlanta.

25. Id.

26. Id.

27. Id.

28. 391 U.S. 430 (1968).

29. Id. at $439-41$.

30. Freeman, 112 S. Ct. at 1436.

31. Id.

32. Id. The plan proposed closing each of the district's all-black schools and establishing neighborhood school attendance zones. Brief of Petitioners, Freeman (No. 89-1290). The DCSS/HEW plan was implemented at the start of the 1969-1970 school year. Freeman, 112 S. Ct. at 1436. Although there remains some dispute over the issue, see note 23 supra, DCSS schools apparently were "effectively desegregated" for a period of time immediately following the adoption of the DCSS/HEW plan. Freeman, 112 S. Ct. at 1439. Contra id. at 1455 (Blackmun, J., concurring) (arguing that "the students in DeKalb County, Ga., never [had] attended a desegregated school system even for one day"). 
students grew from 5.6 percent to 47 percent of the student population. ${ }^{33}$ At the same time, segregated residential patterns developed in DeKalb County. ${ }^{34}$ The combination of these demographic changes and DCSS's policy of assigning students based on neighborhood attendance zones led to the development of several predominantly one-race schools. ${ }^{35}$

After seventeen years of court supervision, DCSS in 1986 petitioned the district court for a declaration that it had achieved unitary status and sought final dismissal of the litigation. ${ }^{36}$ The district court analyzed DCSS's progress toward unitary status using a set of factors identified by the Supreme Court in Green as indicative of a school system's compliance with its desegregation obligation. ${ }^{37}$ These factors (or "Green areas") direct the focus of a court's inquiry to primary aspects of a school system's operations: student assignment, faculty, staff, transportation, extracurricular activities, and physical facilities. ${ }^{38}$ Since Green, the Supreme Court has generally exhorted lower courts to examine each Green area when deciding whether a school district is unlawfully segregated. ${ }^{39}$ The Green factors have therefore provided a useful framework to guide district courts' inquiries into constitutional compliance. ${ }^{40}$

In Freeman, the district court analyzed each Green area independently and

33. Freeman, $112 \mathrm{~S} . \mathrm{Ct}$. at 1438 . From 1976 to 1986 , the overall student population remained stable at around 70,000. Id. Enrollment in elementary schools decreased overall by $15 \%$, but enrollment of African-American students increased by $86 \%$. Id. During the same time period, DCSS high school enrollment decreased by $16 \%$, while African-American student enrollment increased by $119 \%$. Id.

34. Id. In 1969, the county was well integrated residentially, but by 1986 the northem half of the county had become predominantly white and the southern half almost entirely African-American. Id. Present-day DeKalb County is to a large extent residentially segregated. Id.

35. Id. In the 1986-1987 school year, 50\% of DCSS's black students attended schools where the student population was at least $90 \%$ black, and $62 \%$ of DCSS's black students attended schools whose proportion of black students was more than $20 \%$ greater than the system-wide average. Id. Twentyseven percent of white DCSS students attended schools that were at least $90 \%$ white, and $59 \%$ attended schools whose white student population exceeded the system-wide average by more than $20 \%$. Id. Five of 22 high schools and 18 of 74 elementary schools were more than $90 \%$ black. Id. Five high schools were at least $80 \%$ white, and 10 elementary schools were at least $90 \%$ white. Id.

36. Id. at 1437. DCSS's desegregation plan underwent little modification between its adoption and 1986. In 1972, DCSS implemented a Majority-to-Minority (M-to-M) transfer plan. Id. at 1440. The M-to-M plan permitted a limited number of students to transfer from a school in which they were a member of the racial majority to one at which they were a racial minority. Id. at 1437. By the 19861987 school year, 4500 of DCSS's 72,000 students were participating in the program. Id. at 1440. During the 1980s, DCSS implemented a magnet school program and some "experience programs," both of which encouraged integration of the district's students. Id. A magnet school program consists of "a school with a special educational program designed to attract voluntary transfers from outside the area, thus producing integration without compulsion." Gary Orfield, Must We Bus? SeGregated SCHOOLs AND National Policy 133 n.52 (1978). Frequently these programs are designed to attract highly talented students or students interested in a particular discipline (e.g., science).

37. Freeman, 112 S.Ct. at 1437.

38. Green v. County Sch. Bd., 391 U.S. 430,435 (1968). In Green, the Court emphasized that school desegregation "extend[ed] not just to the composition of student bodies at the two schools but to every facet of school operations." Id.

39. See, e.g., Pasadena Bd. of Educ. v. Spangler, 427 U.S. 424, 436 (1976) (analyzing the school district's compliance in student assignment independent of compliance in other areas such as the hiring and promotion of teachers and administrators); Swann v. Charlotte-Mecklenburg Bd. of Educ., 402 U.S. 1, 18 (1971) (stating that "existing policy and practice with regard to faculty, staff, transportation, extracurricular activities, and facilities were among the most important indicia of a segregated system").

40. See, e.g., Freeman, 112 S. Ct. at 1443 (stating that "[ $t$ ]he Green factors are a measure of the racial identifiability of schools in a system that is not in compliance with Brown" and that "district 
found that DCSS had achieved only partial compliance. ${ }^{41}$ DCSS had successfully desegregated the areas of student assignment, physical facilities, transportation, and extracurricular activities, but remained unlawfully segregated with respect to faculty assignment, staff assignment, and quality of education. ${ }^{42} \mathrm{In}$ stead of retaining supervision over the entire system, however, the district court opted for a rather unique approach: It returned control over DCSS's "unitary" Green areas to local authorities, while retaining supervision over those areas that remained unlawfully segregated. ${ }^{43}$ On appeal, the Eleventh Circuit rejected the district court's incremental withdrawal of supervision. ${ }^{44}$ The court of appeals held that, as a matter of law, district courts may not relinquish control over any area of a school district's operations until the school district has completely desegregated. ${ }^{45}$

In a unanimous judgment, ${ }^{46}$ the Supreme Court reversed the Eleventh $\mathrm{Cir}$ cuit, affirming much of the district court's decision. Writing for the Court, Justice Kennedy stated that the "duty and responsibility of a school district once segregated by law is to take all steps necessary to eliminate the vestiges of

courts [should] fashion remedies that address all these components of elementary and secondary school systems").

41. Id. at $1437-42$.

42. Id. at 1437. The district court first analyzed DCSS's compliance with respect to student assignment and held that, when DCSS closed its all-black schools in 1969 and implemented a racially neutral system of pupil assignment based on neighborhood attendance zones, DCSS had already desegregated that area of its operations. Id. at 1439. The court found that disproportionate racial concentration of DCSS students in 1986 was due to voluntary demographic shifts and was not attributable to any action by the school district. Id. at 1439-41. Accordingly, the court concluded that DCSS had achieved "maximum practical desegregation" with respect to student assignment. Id. at 1440.

The district court then evaluated DCSS's compliance in each of the remaining Green areas. The court found that the school system assigned a disproportionate number of African-American teachers and administrators to predominantly black schools and concluded that DCSS remained unlawfully segregated with respect to this area. Id. at 1441. In assessing the relative quality of education in DeKalb schools, the court found that the faculties in predominantly white schools were better educated and more experienced than their counterparts in predominantly African-American schools. Id. at 1442. In addition, per pupil expenditure was higher in predominantly white than in predominantly black schools. Id. Consequently, the court found DCSS still in noncompliance with regard to the disparity in the quality of its students' educations. Id. Finally, with respect to facilities, transportation, and extracurricular activities, the district court concluded that DCSS had successfully desegregated these areas. Id.

43. Id.

44. Pitts v. Freeman, 887 F.2d 1438 (11th Cir. 1989), rev'd, 112 S. Ct. 1430 (1992).

45. Id. at 1450. The Eleventh Circuit affirmed the district court's decision in part and reversed in part. Id. The court of appeals agreed with the district court's finding that DCSS had not achieved unitary status and that the district court should retain jurisdiction. Id. at 1450. However, the Eleventh Circuit disagreed with the trial court's holding that a district court may incrementally withdraw its supervision over a school district after a desegregation order. Id. at 1446-47. DCSS appealed this part of the decision, and the Supreme Court granted certiorari on the issue of "whether a district court may relinquish its supervision and control over those aspects of a school system in which there has been compliance with a desegregation decree if other aspects of the system remain in noncompliance." Freeman, 112 S. Ct. at 1443.

46. Although the judgment was unanimous, the Court was divided in its reasoning. Only Chief Justice Rehnquist and Justices Scalia, Souter, and White joined Justice Kennedy's opinion for the Court. Despite joining Justice Kennedy's opinion, Justices Scalia and Souter each wrote separate concurrences expressing widely disparate opinions about the role of federal courts in school desegregation. Id. at 1450,1454 . Justice Blackmun wrote his own concurrence, joined by Justices Stevens and O'Connor, expressing still different reasoning. Id. at 1455 . Justice Thomas participated in neither the consideration nor decision of the case. 
the unconstitutional de jure system." 47 The Court recognized that Green and subsequent decisions provide important guidance to district courts in evaluating whether formerly segregated school districts have successfully achieved unitary status. ${ }^{48}$ But Justice Kennedy noted that while the concept of unitary status had been "helpful" in defining the scope of an appropriate remedy, it should not "confine the discretion and authority of the District Court[s]."49

Justice Kennedy next discussed the Court's holding in Pasadena Board of Education v. Spangler. ${ }^{50}$ In that case, the Court had ruled that the "District Court exceeded its remedial authority in requiring annual readjustment of school attendance zones" when racial imbalance in student enrollment was attributable to voluntary demographic shifts rather than discrimination by the school district. ${ }^{51}$ Quoting from Spangler, the Freeman Court stated that once a district court has " implemented a racially neutral attendance pattern ... the District Court ha[s] fully performed its function of providing the appropriate remedy for previous racially discriminatory attendance patterns.' "52

The Court stated that the logic of Spangler determined the result in Freeman. Maintaining that it was only "mak[ing] explicit the rationale that was central in Spangler," 53 the Court held that "federal courts have the authority to relinquish supervision and control of school districts in incremental stages, before full compliance has been achieved in every area of school operations." 54 In cases of partial compliance, district courts may "return control to the school system in those areas where compliance has been achieved, limiting further judicial supervision to operations that are not yet in full compliance with the court decree." 55 In other words, the school district may achieve unitary status in some Green areas before others, and district courts may return control over the desegregated areas to local authorities prior to their achieving full compliance.

The Court justified its holding by emphasizing that judicial supervision has always been "intended as a 'temporary measure." "56 Justice Kennedy noted that local autonomy in decisions affecting elementary and secondary education " "is a vital national tradition," "57 and that the "ultimate objective" of courtordered desegregation has always been to return governance of school systems to local authorities. ${ }^{58}$ The incremental withdrawal of court supervision would,

47. Freeman, 112 S. Ct. at 1443.

48. See text accompanying notes $37-42$ supra.

49. Freeman, 112 S. Ct. at $1443-44$.

50. 427 U.S. 424 (1976).

51. Freeman, 112 S. Ct. at 1444.

52. Id. (quoting Spangler, 427 U.S. at 437).

53. Id.

54. Id. at 1445 .

55. Id. at 1446 .

56. Id. at 1445 (quoting Board of Educ. v. Dowell, 498 U.S. 237, 247 (1991)).

57. Id. (quoting Dayton Bd. of Educ. v. Brinkman, 433 U.S. 406, 410 (1977) (Dayton I)).

58. Id. (stating that, "[a]lthough this temporary measure has lasted decades, the ultimate objective has not changed-to return school districts to the control of local authorities"). The Court had discussed the importance of returning school systems to local control in decisions prior to Freeman. See, e.g., Milliken v. Bradley, 433 U.S. 267, 280-81 (1977) (Milliken II) (stating that "the federal courts 
the Court argued, facilitate a smooth transfer of control over school districts from the judiciary to local officials..$^{59}$

\section{B. Freeman's Misplaced Reliance on Spangler}

In approving the district court's incremental withdrawal of supervision over DCSS, the Court in Freeman relied heavily on Pasadena Board of Education $v$. Spangler. But the Court's contention that Freeman merely makes explicit the rationale of Spangler ${ }^{60}$ ignores important differences between the two cases. While the two decisions are not inconsistent, Spangler in no way compelled the Court's ruling in Freeman to permit incremental withdrawal. Rather, Freeman decided an important unresolved issue in desegregation law without the Court so acknowledging.

\section{The holding in Spangler.}

The issue raised in Spangler was whether the district court had exceeded its authority by ordering the Pasadena Unified School District (PUSD) to insure that "there [was] no school in the District, elementary or junior high or senior high school, with a majority of any minority students." 61 The Court prefaced its discussion by affirming its prior holding in Swann v. Charlotte-Mecklenburg Board of Education, ${ }^{62}$ where the Court stated that there are limits to what courts can require of school districts in fulfilling their obligations to desegregate. ${ }^{63}$ The Spangler Court also reiterated language from Swann concerning district courts' use of fixed proportionalities to achieve racial balance. ${ }^{64}$ While district courts may use mathematical ratios as "a starting point in the process of shaping a remedy," they cannot use them as "an inflexible requirement" in

in devising a remedy must take into account the interests of state and local authorities in managing their own affairs, consistent with the Constitution").

59. Freeman, 112 S. Ct. at 1445 . Some commentators support the Court's increasing emphasis on returning school districts to local control as soon as possible. See, e.g., John E. Canady, Jr., Comment, Overcoming Original Sin: The Redemption of the Desegregated School System, 27 Hous. L. REv. 557,558 (1990) (arguing that "protracted school desegregation litigation saps the strength of educational institutions, is fundamentally unfair to the schools, and leads to confusion about the role of the judiciary in the United States").

60. Freeman, 112 S. Ct. at 1444.

61. Pasadena Bd. of Educ. v. Spangler, 427 U.S. 424, 428 (1976) (quoting Spangler v. Pasadena Bd. of Educ., 311 F. Supp. 501, 505 (C.D. Cal. 1970)). After the district court found that the school district was unlawfully segregated, school officials devised a desegregation plan (the "Pasadena Plan") which included the "no majority of any minority" provision. Id. In the first year under the Pasadena Plan, the school district complied with the court's order with respect to attendance patterns, and minority enrollment did not exceed white enrollment in any PUSD school. Id. at 431. But because of subsequent demographic shifts in Pasadena, PUSD failed to comply literally with this requirement for the next two school years. Id. at 435-36. After operating for four years under the Pasadena PIan, PUSD petitioned the district court for modification of the "no majority of any minority" requirement, but the District Court denied this motion. Id. at 428-29. On appeal, the Ninth Circuit affirmed the District Court's judgment. Id. at 429.

62. 402 U.S. 1 (1971).

63. Spangler, 427 U.S. at 434 . In Swann, the Court stated that no "fixed ... guidelines can be established as to how far a court can go, but it must be recognized that there are limits." 402 U.S. at 28.

64. Spangler, 427 U.S. at 434. 
fashioning desegregation orders. 65 Consequently, "[n]either school authorities nor district courts are constitutionally required to make year-by-year adjustments of the racial composition of student bodies once the affirmative duty to desegregate has been accomplished and racial discrimination through official action is eliminated from the system." 66

Comparing the "no majority of any minority" requirement against this language in Swann, the Spangler Court concluded that "the inconsistency between the two is clear." 67 According to the Court, PUSD's implementation of its desegregation plan established a nondiscriminatory system of student assignment. 68 The school district had therefore discharged its affirmative duty to desegregate with respect to student assignment and "the District Court had fully performed its function of providing the appropriate remedy for previous racially discriminatory attendance patterns." 69 All resegregation occurring subsequent to the plan's implementation was due to "people randomly moving into, out of, and around the PUSD area."70 Because the disparities were the result of de facto residential segregation, the Court could not order the school district to counteract them. Thus, in "requir[ing] annual readjustment of attendance zones so that there would not be a majority of any minority in any Pasadena public school, the District Court exceeded its authority."71

Most importantly for Freeman's analysis, the Spangler Court held that PUSD had discharged its duty to desegregate student attendance despite indications that PUSD had yet to comply with other aspects of its desegregation order. ${ }^{72}$ Writing for the Court, Chief Justice Rehnquist conceded that the school district may not have successfully eliminated discrimination in the hiring and promotion of faculty and staff. ${ }^{73}$ But the Court reasoned that the continued existence of unlawful segregation in certain areas does not undercut the force of the principle expressed in Swann: A court cannot order a school district to readjust its attendance patterns once it has fulfilled its "affirmative duty to desegregate." 74

Ultimately, Spangler stands for three propositions: (1) courts are limited as to the affirmative steps they can require a school district to undertake under a desegregation order; (2) this limit is by definition the point at which the school district has eliminated all vestiges of the unlawfully segregated system; and (3) a school system may eliminate such vestiges sequentially, and may therefore discharge its duty to desegregate in some Green areas before others. Impor-

65. Swann, 402 U.S. at 25.

66. Id. at $31-32$.

67. Spangler, 427 U.S. at 434.

68. Id. at 436-37.

69. Id. at 437.

70. Id. at $435-36$.

71. Id. at 435 .

72. Id. at 436; see also Thomas E. Chandler, The End of School Busing? School Desegregation and the Finding of Unitary Status, 40 OkLA. L. REv. 519, 530 (1987) (contending that " $[t]$ he Spangler decision is important" because it "divided the concept of a unitary school system into component parts that can be treated separately").

73. Spangler, 427 U.S. at 436.

74. Id. (quoting Swann v. Charlotte-Mecklenburg Bd. of Educ., 402 U.S. 1, 32 (1971)). 
tantly, the Spangler decision did not address the issue of whether, having satisfied its duty to desegregate student attendance, PUSD was entitled to autonomy to implement any student assignment plan of its choosing. More broadly, Spangler left unanswered the question of whether a court that cannot require a school system to take further affirmative steps to desegregate a particular Green area must still prevent the school district from taking actions that, although not motivated by discrimination, have segregatory effects.

\section{Nuances of the holdings in Freeman and Spangler.}

By allowing district courts to relinquish control over unitary Green areas, Freeman implicitly held that a formerly segregated school system's only obligation in each such area is the duty to take affirmative steps to desegregate. Once individual Green areas are successfully desegregated, district courts have the discretion to limit their supervision to those areas in which the school district has yet to achieve compliance. ${ }^{75}$ Freeman therefore viewed Spangler's definition of the constitutional obligations of a formerly de jure school system with respect to each Green area as binary: Either the school district has an obligation to take affirmative steps to desegregate, or it has no duties at all.

Because the Court lacked clear precedent on the issue, its decision to permit incremental withdrawal of supervision is consistent with developed desegregation jurisprudence. What seems unjustifiable about Freeman is the Court's failure to address explicitly whether nonunitary school districts must refrain from taking actions which have de facto segregatory effects. The decision in Freeman completely overlooks the distinction between a school district's obligation to take affirmative steps to desegregate-which Spangler addressed-and the school district's duty to refrain from actions that would have a de facto segregatory impact. This distinction is indeed a subtle one, but the Freeman Court's contention that it was merely reaffirming Spangler is nevertheless clearly inaccurate. The Court in fact resolved an important outstanding issue in desegregation law without a candid discussion of the merits of the issue.

\section{The problems inherent in Freeman's holding.}

Freeman's binary conception of a formerly segregated school district's obligations under Brown is appropriate in describing the system's compliance as a whole. Once the school district has completely desegregated, it has satisfied its constitutional obligations, and court supervision is appropriately withdrawn. But this framework does not make much sense when applied to Green areas individually. A multitier framework that requires school districts to refrain from aggravating existing segregation until they have completely desegregated would be more appropriate in this context.

There are several compelling reasons for requiring nonunitary school districts to desist from enacting policies that have de facto segregatory effects. For instance, partially compliant school systems have yet to fully satisfy their

75. Freeman v. Pitts, 112 S. Ct. 1430, 1446-47 (1992). 
constitutional obligations and remain, as a whole, unlawfully segregated. One might fear that, unless school systems are enjoined from taking actions with segregative effects, released areas may become de facto resegregated prior to the school system fully complying with the Constitution. Such resegregation in formerly unitary areas may in turn inhibit school districts' progress toward desegregation in other Green areas. And, as the Court itself has stated, a formerly segregated school system's affirmative duty to desegregate includes "the obligation not to take any action that would impede the process of disestablishing the dual system and its effects."76

Construing school districts' obligations with respect to individual Green areas to include a duty to refrain from de facto segregatory actions even after achieving compliance in that area would have allayed these important concerns. The Freeman Court chose instead to emphasize the importance of returning control to local authorities at the earliest practicable date. Consequently, the Court held that a school district's successful desegregation of a Green area relieves it of all obligations in that area.

\section{Redefining Untary Status}

A second important implication of the Court's holding in Freeman is that it effectively redefined unitary status. It did so in the first instance by describing discrete aspects of DCSS as "unitary." Before Freeman, the Court had applied the expression only to entire school districts that had eliminated all vestiges of the discriminatory system. ${ }^{77}$ Even in Spangler, where the Court approved the separate analysis of Green areas, the Court did not use the term "unitary" to describe individual aspects of PUSD's operations. ${ }^{78}$ By doing so in Freeman, the Court divorced the concept from its essential meaning-the elimination of all vestiges of the racially discriminatory system.

Freeman's approval of incremental withdrawal also altered the meaning of unitary status in a more fundamental way. Since Brown, the essential question addressed by the courts in desegregation litigation has been whether the formerly segregated school district is operating in a "racially nondiscriminatory" fashion. ${ }^{79}$ Inquiry into whether a school district has successfully desegregated has focused broadly on school systems as a whole rather than narrowly on discrete facets of such systems. For instance, the Court stated in Green that "the question [is] whether the Board has achieved the 'racially nondiscrimina-

76. Dayton Bd. of Educ. v. Brinkman, 443 U.S. 526, 538 (1979). The Court expressed the same concern in Wright v. Council of Emporia, 407 U.S. 451 (1972), approving the district court's rejection of a school system's attempt to divide itself into two separate school districts because "its effect would .. impede the process of dismantling a dual system." 460 U.S. at 470.

Recent circuit court opinions suggest that school systems may retain residual obligations after discharging their duty to take affirmative steps to desegregate in specific Green-type areas. For example, in Harris v. Crenshaw Board of Education, 968 F.2d 1090 (11th Cir. 1992), the court stated that nonunitary school districts "are obligated ... to avoid any official action that has the effect of perpetuating or reestablishing a dual system." Id. at 1095.

77. See note 4 supra and accompanying text.

78. See Pasadena Bd. of Educ. v. Spangler, 427 U.S. 424 (1976).

79. Brown v. Board of Educ., 349 U.S. 294, 301 (1955) (Brown II). 
tory school system" " mandated by Brown. ${ }^{80}$ Green further noted that "[t]he obligation of the district courts, as it always has been, is to assess the effectiveness of a proposed plan in achieving desegregation," 81 and defined desegregation as the "conversion of a state-imposed dual system to a unitary, nonracial system." 82 A year later, in United States v. Montgomery County Board of Education, ${ }^{83}$ the Court described "the basic task" of formerly de jure systems as "achieving a public school system wholly free from racial discrimination." 84 As the Court explained in Swann, "[t]he objective [is] to eliminate from the public schools all vestiges of state-imposed segregation." 85 The Court reiterated in Columbus Board of Education v. Penick 86 that, "[w]here a racially discriminatory school system has been found to exist, Brown II imposes the duty on local school boards to "effectuate a transition to a racially nondiscriminatory school system.' "87

Thus, the determination of whether school districts have successfully desegregated has historically consisted of more than consideration of the Green factors alone. Rather, district courts have more broadly examined whether school systems are providing their students with a nonracial, nondiscriminatory education. Although the Green factors have guided a district court's inquiry, they have not defined it. They have been no more than a measure of a school district's progress toward desegregation. For instance, at their inception in Green, the Court invoked them only to illustrate the extent of the system's segregation.88 Similarly, the Court in Swann stated that the Green factors "were among the most important indicia of a segregated system." 89 Moreover, in Freeman itself, the Court stated that " $[t]$ he Green factors are a measure of the racial identifiability of schools in a system that is not in compliance with Brown." 90

The Green factors provide a framework for evaluating a school system's compliance, but a supervising district court's inquiry has not been limited to these areas alone. The question of whether an unlawfully segregated school district has achieved unitary status has always been greater than the sum of its Green factor parts.91 As the Court suggested in Freeman, there may be impor-

80. Green v. County Sch. Bd., 391 U.S. 430, 437 (1968) (quoting Brown II, 349 U.S. at 301).

81. Id. at 439.

82. Id. at 441 . The Court also emphasized that school districts must "take whatever steps might be necessary to convert to a unitary system in which racial discrimination would be eliminated root and branch." Id. at 437-38.

83. 395 U.S. 225 (1969).

84. Id. at 232. This language was also quoted (and given emphasis) in Milliken v. Bradley, 433 U.S. 267, 282-83 (1977) (Milliken II).

85. Swann v. Charlotte-Mecklenburg Bd. of Educ., 402 U.S. 1, 15 (1971) (emphasis added).

86. 443 U.S. 449 (1979).

87. Id. at 458 (quoting Brown II, 349 U.S. at 301).

88. See Green v. County Sch. Bd., 391 U.S. 430,435 (1968).

89. Swann, 402 U.S. at 18 (emphasis added).

90. Freeman v. Pitts, 112 S. Ct. 1430, 1443 (1992) (emphasis added).

91. See Brief for the Lawyer's Committee for Civil Rights Under Law as Amicus Curiae in Support of Respondents at 15, Freeman, 112 S. Ct. at 1430 (No. 89-1290) ("If particular discriminatory practices are considered incrementally and in isolation, the sum of the parts of the system will be less 
tant additional indicators worthy of consideration in evaluating compliance.92 In addition to the Freeman majority's acknowledgment that the Green factors "need not be a rigid framework," "93 Justice Souter reiterated that "Green's list of specific factors need not be treated as exclusive."94 Indeed, Justice Kennedy's opinion approved of the district court's use of quality of education as an additional Green factor, stating that "[i]t was an appropriate exercise of [the district court's] discretion" not only to address the factors discussed in Green but also "to inquire whether other elements ought to be identified." 95

Freeman's approval of area-by-area withdrawal, however, significantly narrows the breadth of a district court's analysis. Once a district court articulates its criteria for measuring a school district's progress toward unitary statuseven if it selects other criteria in addition to the traditional Green factors-its inquiry is necessarily limited to the chosen factors. From that point forward, unitary status, by definition, equals the school district's satisfying its affirmative duty to desegregate each selected area. ${ }^{96}$ Thus, in cases where the district court withdraws supervision incrementally, Freeman implicitly elevates the selected Green areas to the exclusive indicia of compliance. Achieving compliance in each Green area essentially becomes an end in itself rather than a measure of overall compliance. The implication of Freeman, therefore, is that, once a school district has incrementally desegregated each articulated area, the district court may declare the system unitary even if the school district remains segregated as measured by other criteria. ${ }^{97}$ As a result, actual vestiges of the discriminatory system not captured by the enumerated Green areas may persist even after the school district is declared unitary and the litigation is dismissed.

This implication of Freeman is particularly troubling because it permits district courts to ignore one of the most significant manifestations of segregation: the racial identifiability of a district's schools. ${ }^{98}$ As the Court has repeatedly emphasized, the elimination of racial identifiability from a system's schools is vital to remedying the harm caused by intentional segregation. ${ }^{99}$ Indeed, prior to Freeman, school districts that failed to eliminate the racial identifiability of

than the Constitutionally mandated whole-a school system cleansed of the vestige of de jure segregation").

92. Freeman, 112 S. Ct. at $1446-47$.

93. Id.

94. Id. at 1454 n.l (Souter, J., concurring).

95. Id. at 1446 .

96. Note that this is true if, at the time the district court announces the Green areas with which it will evaluate the school district's progress toward unitary status, the school system has achieved compliance in all, some, or none of the articulated areas. Regardless, the district court's inquiry is limited to evaluating independent compliance in each discrete area.

97. For instance, in Freeman, the seven factors used by the district court to evaluate compliance-student assignments, transportation, physical facilities, extracurricular activities, teacher and staff assignments, resource allocation, and quality of education-may ignore systemwide indications of segregation that combine two or more of these areas.

98. See notes 140-144 infra and accompanying text. A supervising district court may examine whether the school system has eliminated the racial identifiability of its schools, but only if the court selects racial identifiability as a Green criterion for evaluating achievement of unitary status. See text accompanying notes 91-97 supra. However, Freeman neither requires nor suggests that courts use racial identifiability as a Green area.

99. See text accompanying notes 140-144 infra. 
their schools were presumptively still segregated. ${ }^{100}$ But after Freeman, racial identifiability that persists throughout judicial supervision-but which does not constitute segregation observable by the district court in independent evaluations of each Green area-may pass unnoticed and unremedied.

\section{The Perils of Incremental Withdrawal}

\section{A. The Potential for Incremental Resegregation}

Although Freeman's ultimate impact remains uncertain, ${ }^{101}$ its approval of incremental withdrawal may in some cases significantly undermine effective desegregation. In addition to redefining "unitary" so that vestiges of the segregated system may survive judicial supervision undetected, ${ }^{102}$ Freeman increases the likelihood that school districts will de facto resegregate before fully complying with Brown. ${ }^{103}$ Where district courts withdraw their supervision incrementally, school officials will have complete control over released Green areas. As a result, local authorities may lawfully take actions that aggravate existing racial imbalances. ${ }^{104}$ In other words, Freeman allows nonunitary school districts to enact policies that resegregate their schools.

The potential for incremental resegregation-the resegregation of unitary Green areas prior to the school district's achieving full unitary status-certainly existed prior to Freeman. Since Spangler, it has been clear that district courts cannot force a school district to take affirmative steps to keep a particular Green area desegregated once the school system has successfully desegregated that area. ${ }^{105}$ For example, the Freeman opinion indicates that demographic shifts in DeKalb County unrelated to the school district's actions caused resegregation in student assignment before the school district achieved unitary status in all areas. ${ }^{106}$ But because the school district had fulfilled its affirmative duty to desegregate with respect to student assignments, the district court lacked the authority to compel the district to take affirmative steps to redress these racial disparities. What is unprecedented about Freeman is that it permits school districts themselves to take actions that contribute to such resegregation. Freeman implicitly allows unlawfully segregated school systems to take steps that reverse the process of desegregation so long as such steps are not motivated by discriminatory intent. By increasing the likelihood

100. See, e.g., Brown v. Board of Educ., 892 F.2d 851, 866 (10th Cir. 1989) (stating that the presence of racially identifiable schools in a previously de jure system dispositively proves that the school district remains unlawfully segregated), vacated, 112 S. Ct. 1657 (1992), reinstated, 978 F.2d 585 (10th Cir. 1992), cert. denied, 113 S. Ct. 2994 (1993) (Brown III).

101. Freeman's effect on desegregation litigation will remain unclear until the Court decides what showing plaintiffs will have to make for district courts to regain supervision over Green areas released to local authorities. See text accompanying notes 162-168 infra.

102. See notes $96-98$ supra and accompanying text.

103. Such de facto resegregation does not raise constitutional concerns unless it is traceable to the discriminatory system. See note 7 supra.

104. See Brief for the Lawyers' Committee for Civil Rights Under Law, supra note 91, at 15-16.

105. See Pasadena Bd. of Educ. v. Spangler, 427 U.S. 424, 436-37 (1976); text accompanying notes 70-74 supra.

106. Freeman, $112 \mathrm{~S}$. Ct. at 1438; see also text accompanying notes $32-35$ supra. 
of incremental resegregation, Freeman significantly increases the possibility that, despite years of judicial supervision, school districts will never truly desegregate.

In his concurring opinion in Freeman, Justice Souter raised the issue of incremental resegregation. But he limited his discussion to resegregation attributable to remaining vestiges of the segregated system: "Even after attaining compliance as to student composition, other factors such as racial composition of the faculty, quality of the physical plant, or per-pupil expenditures may leave schools racially identifiable." "107 He further recognized that the racial identifiability of the schools may in turn influence demographic shifts that tend to resegregate the district. 108 "In such a case," Justice Souter wrote, "the vestige of discrimination in one factor will act as an incubator for resegregation in others." $109 \mathrm{He}$ concluded that district courts should determine that such resegregation presents "no immediate threat" before declaring a Green area unitary. ${ }^{110}$

By limiting his discussion to resegregation causally related to vestiges of the unlawfully segregated system, however, Justice Souter did not address the potential for resegregation due to actions taken by the school district itself. The resegregation of released Green areas instigated by school officials' actionsunless somehow influenced by lingering segregation in nonunitary areas-is entirely unrelated to the school district's original constitutional violation. As such, it is not a vestige of the discriminatory system. Thus, even accepting Justice Souter's opinion as the law, district courts lack the authority to prevent incremental resegregation attributable to the affirmative acts of school officials. ${ }^{111}$

Previous desegregation cases illustrate that, after achieving unitary status and being completely released from judicial supervision, school systems are susceptible to de facto resegregation. ${ }^{112}$ The Supreme Court squarely addressed the issue of such resegregation in Board of Education v. Dowell. ${ }^{113}$ In 1963, a district court found that the Oklahoma City Public School Board had intentionally segregated its schools by race and ordered the Board to dismantle its de jure system. ${ }^{114}$ After supervising the school system for nine years under the initial order, the district court found that the school system was still "dual," and in 1972 ordered the implementation of a remedial scheme known

107. Freeman, 112 S. Ct. at 1454-55 (Souter, J., concurring).

108. Id. at 1455 .

109. Id.

110. Id. Because this type of resegregation is technically a vestige of the discriminatory system, however, it may be combatted by the district court. See id. Freeman does not disturb the basic notion that vestiges of past discrimination that linger in the school system are within the reach of district courts.

111. Unless the resegregation is directly traceable to past constitutional violations by the school district, it is not a vestige of the discriminatory system and is not subject to judicial remedy. Id. at 1448 .

112. See, e.g., Theodore M. Shaw, Missouri v. Jenkins: Are We Really a Desegregated Society?, 61 FORDHAM L. REv. 57, 60 (1992) (commenting that once a school district is removed from court supervision, segregated housing patterns may lead to resegregation of schools).

113. 498 U.S. 237 (1991).

114. See Dowell v. School Bd., 219 F. Supp. 427, $447-48$ (W.D. Okla. 1963). 
as the "Finger Plan."115 Five years later, the district court determined that the Oklahoma City schools had achieved unitary status and relinquished jurisdiction over the case. ${ }^{116}$ Nevertheless, the school district voluntarily continued to operate under the Finger Plan until 1985. In that year, school officials initiated the Student Reassignment Plan (SRP). ${ }^{117}$ The SRP discontinued mandatory remedial busing for students in kindergarten through fourth grade and instead assigned these students based on neighborhood attendance zones. ${ }^{118}$ Because of extensive residential segregation in Oklahoma City, the SRP resulted in several predominantly one-race schools, and plaintiffs challenged its implementation as unconstitutional. ${ }^{119}$

The Supreme Court held that the district court's desegregation order bound the Oklahoma City school district only as long as it remained nonunitary. ${ }^{120}$ Writing for the Court, Chief Justice Rehnquist stated that desegregation decrees "are not intended to operate in perpetuity."' 121 Instead, a school district is relieved of the requirements of a desegregation order once it has complied in good faith with the district court's decree and eliminated segregation traceable to the discriminatory system "to the extent practicable." 122

The Court's holding in Dowell makes clear that, absent discriminatory in-

115. Dowell, 498 U.S. at 241; see also Dowell v. Board of Educ., 338 F. Supp. 1256 (W.D. Okla.), aff'd, 465 F.2d 1012 (10th Cir.), cert. denied, 409 U.S. 1041 (1972).

116. Dowell, 498 U.S. at 237, 241-42.

117. Id. at 242 .

118. Id.

119. Id. The plaintiffs claimed that "[u]nder the SRP, 11 of 64 elementary schools would be greater than $90 \%$ black, 22 would be greater than $90 \%$ white plus other minorities, and 31 would be racially mixed." Id. The district court held that, because Oklahoma City schools had been effectively integrated under the Finger Plan, the school district had achieved unitary status and the case should not be reopened. Dowell v. Board of Educ., 606 F. Supp. 1548, 1555-57 (W.D. Okla. 1985). The Tenth Circuit reversed and remanded the case to the district court. Dowell v. Board of Educ., 795 F.2d 1516 (10th Cir.), cert. denied, 479 U.S. 938 (1986). On remand, the district court again found that existing segregation was not a vestige of the formerly de jure system and that the SRP had not been adopted with discriminatory intent. Dowell v. Board of Educ., 677 F. Supp. 1503, 1526 (W.D. Okla. 1987). As a result, the school board had fulfilled its obligations under the desegregation order and was allowed to retain control of the district. Id. On appeal, the Tenth Circuit again reversed, holding that school districts may extricate themselves from the obligations of a desegregation decree only upon a showing of " 'dramatic changes in conditions unforeseen at the time of the decree that both render the protections of the decree unnecessary to effectuate the rights of the beneficiary and impose extreme and unexpectedly oppressive hardships" " on the school districts. Dowell v. Board of Educ., 890 F.2d 1483, 1490 (10th Cir. 1989) (quoting Timothy Stoltzfus Jost, From Swift to Stotts and Beyond: Modification of Injunctions in Federal Courts, 64 Tex. L. Rev. 1101, 1110 (1986)), rev'd, 498 U.S. 230 (1991).

One scholar has termed student assignment plans adopted after the withdrawal of court supervision that result in substantial resegregation "retrogression plans." Brian K. Landsberg, The Desegregated School System and the Retrogression Plan, 48 LA. L. REv. 789, 800 (1988). Landsberg analogizes to voting rights law where, although the relevant claims are statutory rather than constitutional, courts have used the term to describe "changes that, although arguably not infected with discriminatory intent, "would lead to a retrogression in the position of racial minorities with respect to their effective exercise of the electoral franchise.' "Id. at 800-01 (quoting Beer v. United States, 425 U.S. 130, 141 (1976)). In the context of school desgregation, Landsberg uses the term to "refer[ ] to a plan of student assignment which, while arguably not adopted with discriminatory intent, significantly increases the number of minority students attending one-race schools." Id. at 801.

120. Dowell, 498 U.S. at 237, 249.

121. Id. at 248.

122. Id. at 250 . 
tent, unitary school systems may implement any policies they choose..$^{123} \mathrm{~A}$ school district that was once unlawfully segregated but that has successfully desegregated and been declared unitary is no different than a school district never tainted by segregation. As a result, once a court declares a school system unitary, the school district "no longer requires court authorization for the promulgation of policies and rules." 124 A unitary school system is therefore free to take actions (such as Oklahoma City's implementation of the SRP) that exacerbate existing racial imbalances provided they are not motivated by discrimination. De facto resegregation of school districts after they have been declared unitary lies outside the scope of judicial remedy. ${ }^{125}$

Given Dowell's conception of unitary status, Freeman apparently allows partially compliant school districts to implement any nondiscriminatory policy in those Green areas that the district court has declared unitary. Consider, for instance, a school district like DCSS that has discharged its affirmative duty to desegregate student assignments, transportation, and physical facilities. Once the district court withdraws supervision over these areas, local school officials fully control all decisions concerning the alteration of the district's attendance zones, the continuation of busing plans, which schools to close, and the location of new schools and magnet programs. Each of these decisions may aggravate existing racial imbalances. ${ }^{126}$ For instance, if declining enrollment forces a school district to close one of its high schools, it could choose to close its most integrated campus. Or, if a district decides to build new schools or establish magnet programs, it could choose to locate them in predominantly one-race neighborhoods. So long as a school district's actions are not motivated by discrimination, Freeman permits the district to implement such measures without judicial interference.

Incremental withdrawal of court supervision may especially hinder the effective desegregation of school systems whose desegregation plans include

123. See notes 17-18 supra and accompanying text.

124. Dowell, 498 U.S. at 250; see also Price v. Austin Indep. Sch. Dist., 945 F.2d 1307, 1315 (5th Cir. 1991) (noting that a finding of unitary status "removes the federal courts from their supervisory role over the Board's decisions"); United States v. Overton, 834 F.2d 1171, 1175 (5th Cir. 1987) (stating that the attainment of unitary status "means that a school board is free to act without federal supervision so long as the board does not purposefully discriminate").

125. One commentator has observed that "unitary school districts [are] free to choose from the myriad of locally accepted methods for assigning students to various schools, including neighborhood school assignments, despite the fact that these methods invariably increase racial concentration in schools." Brown, supra note 4, at 1107 n.7.

126. The Tenth Circuit recently emphasized in Brown III that

courts must recognize that the school district's choices on such questions as where to locate new schools, which schools to close, how to react to overcrowding or underutilization, and what transfer policy to offer, all have obvious impact on the school attendance boundaries the district can draw under a neighborhood school plan. If these choices are not made with an eye toward desegregation, a neighborhood school plan may "further lock the school system into a mold of separation of races."

Brown v. Board of Educ., 892 F.2d 851, 864-65 (10th Cir. 1989) (quoting Swann v. Charlotte-Mecklenburg Bd. of Educ., 402 U.S. 1, 21 (1971)) (footnote omitted), vacated, 112 S. Ct. 1657 (1992), reinstated, 978 F.2d 585 (10th Cir. 1992), cert. denied, 113 S. Ct. 2994 (1993). 
busing schemes or gerrymandered attendance zones. ${ }^{127}$ Such plans are common where the effected community is residentially segregated so that neighborhood attendance zones alone would not desegregate the school system.128 Because busing and gerrymandered attendance zones are usually costly and administratively inconvenient, school districts are apt to abandon such plans once the district court has withdrawn supervision. ${ }^{129}$ If school officials adopt neighborhood attendance zones instead, these school districts likely will resegregate rapidly. ${ }^{130}$

The Freeman Court partially anticipated that incremental withdrawal might raise the potential for resegregation and included a safeguard against this result. "Among the factors which must inform the sound discretion of the court in ordering partial withdrawal," wrote Justice Kennedy, is "whether retention of judicial control is necessary or practicable to achieve compliance with the decree in other facets of the school system." 131 Thus, district courts should retain supervision over desegregated Green areas if foreseeable de facto resegregation of those areas would impede the school district's progress toward unitary status in areas that remain unlawfully segregated.

This safeguard, however, is wholly inadequate to combat the problems created by incremental withdrawal. First, it seeks only to prevent incremental resegregation that the district court can anticipate when it contemplates returning supervision to local authorities. The safeguard therefore is entirely incapable of preventing resegregation caused by school district action subsequent to the court's withdrawal of supervision. Such resegregation by its very nature cannot be anticipated. ${ }^{132}$ Second, even if resegregation is foreseeable, the safeguard only compels district courts to retain supervision when resegregation of the released area is likely to impede the desegregation of nonunitary Green areas. Interference with compliance in other areas, however, is only one of several dangers posed by incremental resegregation, as is explained more fully below. In sum, Freeman offers little protection against incremental resegregation. ${ }^{133}$

127. See Tatel, supra note 18, at 67 ("If [courts] allow busing to end, many schools are likely to return to their segregated status.").

128. For examples of communities where neighborhood attendance plans would not have encouraged desegregation, see Dowell, 498 U.S. at 237, and Swann, 402 U.S. at 1.

129. The Oklahoma City Public School Board adoption of the SRP provides an example of a school district abandoning desegregation efforts once the district court withdrew supervision. See text accompanying notes 116-119 supra.

130. See, e.g., Dowell, 498 U.S. at 242 (resegregation under SRP); Riddick v. School Bd. of Norfolk, 784 F.2d 521 (4th Cir. 1986) (resgregation after elimination of busing plan), cert. denied, 479 U.S. 938 (1986).

131. Freeman v. Pitts, 112 S. Ct. 1430, 1446 (1992).

132. See notes 126-130 supra and accompanying text.

133. An expansive interpretation of Justice Kennedy's safeguard language could conceivably prevent resegregation if district courts were to hold that retaining supervision over all Green areas is "necessary or practicable to achieve compliance with the decree in other facets of the school system." Freeman, 112 S. Ct. at 1446 . But this point is purely academic because, regardless of how a district court construes the safeguard language, it may still retain complete supervision over partially compliant school districts under Freeman. Freeman permits-but does not require-district courts to withdraw supervision incrementally in cases of partial compliance. The danger of Freeman therefore lies in how 


\section{B. The Danger of Perpetuating Racial Identifiability}

The greatest danger posed by incremental resegregation is that it may result in courts declaring school districts unitary without the districts ever having eliminated the racial identifiability of their schools. Racial identifiability most commonly refers to racial disparities in student enrollment. But a school system may perpetuate its schools' racial identifiability through other means. ${ }^{134}$ As the Supreme Court stated in Swann v. Charlotte Mecklenburg Board of Education, 135 " [i]ndependent of student assignment, [it may be] possible to identify a 'white school' or a 'Negro school' simply by reference to the racial composition of teachers and staff, the quality of school buildings and equipment, or the organization of sports activities." 136 Indeed, four of the eight justices participating in the Freeman decision acknowledged that schools may retain their racial identities in ways other than student enrollment. In his concurring opinion, Justice Souter wrote that "[e]ven after attaining compliance as to student composition, other factors such as racial composition of the faculty, quality of the physical plant, or per-pupil expenditures may leave schools racially identifiable." 137 Similarly, Justices Blackmun, O'Connor, and Stevens observed in their concurrence that "[s]chool systems can identify a school as 'black' or 'white' in a variety of ways; choosing to enroll a racially identifiable student population is only the most obvious." 138

Because racial disparities in any aspect of a school system may perpetuate racial identifiability, incremental resegregation may lead to school districts never eliminating the racial identifiability of their schools. Consider, for instance, a school district that has successfully desegregated its student assignments but remains unlawfully segregated with respect to faculty and staff assignments. If returned to local control, enrollment may resegregate before the school district successfully desegregates its faculty and staff. Thus, a significant facet of the school system may remain segregated-either de jure or de facto-at all points before, during, and after the desegregation process.

This problem is aggravated where a school district achieves compliance in different Green areas at widely disparate times. Large time lags will inevitably

it will be used not by courts wishing to retain supervision, but by courts wanting to return control to school officials as quickly as possible.

134. See 1 U.S. Commission on Crvil Rights, Racial Isolation in the Public Schools 2-3 (1967) (stating that "[t]he racial identity of Southern schools . . . is maintained in a variety of ways," including the "continued segregation of teaching staff"); ORFIELD, supra note 36, at 369 (noting that "[t] he racial identity of the schools was reinforced by intense faculty segregation" in Cleveland's public schools); Gary Orfield, School Segregation and Residential Segregation: A Social Science Statement, in School Desegregation: Past, Present and Future 231, 236 (Walter G. Stephan \& Joe R. Feagin eds., 1980) (observing that "[a]ll discriminatory acts by school authorities ... contribute to the racial identifiability of schools," including the assignment of minority teachers to large urban school districts); Karl E. Taeuber, Housing, Schools, and Incremental Segregative Effects, 441 ANnals AM. ACAD. PoL. \& Soc. Scr. 157, 164 (1979) (observing that Milwaukee's student assignment policy, "together with segregative assignment of teachers, have combined to cause, enhance, and maintain the racial identifiability of schools and neighborhoods in Milwaukee").

135. 402 U.S. 1 (1971).

136. Id. at 18 .

137. Freeman, $112 \mathrm{~S}$. Ct. at $\mathbf{1 4 5 4 - 5 5}$ (Souter, J., concurring).

138. Id. at 1457 (Blackmun, J., concurring). 
increase the likelihood that areas released from supervision will resegregate prior to compliance in other areas. ${ }^{139}$ Yet, once the school district achieves unitary status in those areas that remain under judicial supervision, the district court can dissolve its desegregation order regardless of the continued racial identifiability of the schools.

As noted briefly earlier, eliminating the racial identifiability of a system's schools is critical to effective desegregation. 140 Several desegregation decisions have emphasized that racial identifiability is a defining characteristic of discriminatory school districts that court-ordered desegregation seeks to remedy. ${ }^{141}$ The Court stated in Green, for instance, that segregated school systems must "fashion steps which promise realistically to convert promptly to a system without a 'white' school and a 'Negro' school, but just schools." 142 More recently, in United States v. Fordice, ${ }^{143}$ the Court emphasized that it has "consistently asked whether existing racial identifiability is attributable to the State" in determining whether the school system has satisfied its constitutional obligations. ${ }^{144}$

The incremental resegregation of nonunitary school districts creates the danger that court-ordered desegregation will fail to eliminate the racial identifiability of an unlawfully segregated system's schools. According to the Court's own opinions, this should be cause for serious concern. By opening the door for school districts to take actions that resegregate unitary Green areas, Freeman aggravates this danger. As a result, a primary objective of courtordered desegregation may in some cases remain unfulfilled.

\section{The Role of District Courts in Preventing Incremental RESEGREGATION}

\section{A. The Road Not Taken: Prophylactic Supervision of Nonunitary Green Areas}

After Spangler, district courts could not require school districts to take affirmative steps to prevent unitary Green areas from resegregating. But consis-

139. For instance, DCSS had fulfilled its affirmative duty to desegregate with respect to student assignment as early as 1972, when it had closed its all-black schools and operated under a racially neutral pattern of student assignment for three years. Id. at 1439. DCSS had yet to desegregate with respect to the assignment of teachers by 1987. Id. at 1442. By that time, student assignment had de facto resegregated because of the combination of residential patterns and the policy of assigning students based on neighborhood attendance zones. See notes 32-35 supra and accompanying text.

140. See text accompanying notes $98-100$ supra. In the last desegregation case he participated in prior to leaving the Bench, Justice Marshall wrote: "Against the background of former state-sponsorship of one-race schools, the persistence of racially identifiable schools perpetuates the message of racial inferiority associated with segregation. Therefore, such schools must be eliminated whenever feasible." Board of Educ. v. Dowell, 498 U.S. 237, 263 (1991) (Marshall, J., dissenting).

141. See notes $98-100$ supra and accompanying text.

142. Green v. County School Bd., 391 U.S. 430, 442 (1968).

143. 112 S. Ct. 2727 (1992).

144. Id. at 2735; see also Bazemore v. Friday, 478 U.S. 385, 408 (1986) (White, J., concurring) ("The mere continued existence of single race [state-run] clubs does not make out a constitutional violation."'); Pasadena Bd. of Educ. v. Spangler, 427 U.S. 424, 434 (1976) (courts may not interfere with a school district's operation unless "school authorities have in some manner caused unconstitutional segregation"). 
tent with its holding in Spangler, the Court in Freeman could have ruled that district courts may not release any Green areas from supervision until the entire system is successfully desegregated. Specifically, the Court could have required district courts to screen all proposed changes in school policies affecting unitary facets of school systems. Such prophylactic supervision of unitary areas would be consistent with the limitations imposed by Spangler but would prevent school districts from implementing policies that aggravate existing racial disparities before the school system has fully desegregated. By allowing district courts to gradually return control to local authorities, Freeman disregards this potentially valuable intermediate stage in a school district's transition from a dual to a unitary system.

Figure 1 illustrates the potential role of prophylactic supervision in cases of partial compliance. It compares how district courts would scrutinize school district actions involving Green areas over which school officials have retained control under Freeman with how courts would scrutinize these same actions under a prophylactic approach.

\section{Figure 1: Spectrum of Possible Actions by School Systems Concerning Unitary GreEN Areas}

\begin{tabular}{|c|c|c|c|c|}
\cline { 2 - 5 } \multicolumn{1}{c|}{} & $\begin{array}{c}\text { Discriminatory } \\
\text { Action with } \\
\text { Intent to } \\
\text { Segregate }\end{array}$ & $\begin{array}{c}\text { Non-discriminatory } \\
\text { Action with } \\
\text { Segregatory } \\
\text { Effects }\end{array}$ & $\begin{array}{c}\text { Action Without } \\
\text { Segregatory } \\
\text { Effects }\end{array}$ & $\begin{array}{c}\text { Affirmative } \\
\text { Steps to } \\
\text { Remedy } \\
\text { Segregation }\end{array}$ \\
\hline $\begin{array}{c}\text { Under Freeman } \\
\text { Approach }\end{array}$ & Unconstitutional & Acceptable & Acceptable & $\begin{array}{c}\text { Acceptable but } \\
\text { not Required }\end{array}$ \\
\hline $\begin{array}{c}\text { Under Court- } \\
\text { Supervised } \\
\text { Prophylactic Approach }\end{array}$ & Unconstitutional & Blocked by Court & $\begin{array}{c}\text { Court's } \\
\text { Discretion, } \\
\text { [ikely } \\
\text { Acceptable }\end{array}$ & $\begin{array}{c}\text { Acceptable but } \\
\text { not Required }\end{array}$ \\
[G] & {$[\mathrm{F}]$} & [B] & \\
\hline
\end{tabular}

Whether under prophylactic supervision or not, school systems may not implement policies motivated by discriminatory intent (points $[A]$ and $[E]$ ). ${ }^{145}$ Similarly, prophylactic supervision likely would not affect school district actions that neither aggravate nor mitigate racial disparities (points [C] and [G]); these actions would remain acceptable. ${ }^{146}$ Prophylactic supervision also would

145. See note 6 supra and accompanying text.

146. Technically, if a district court were to retain supervision, a school system would need prior approval before enacting a neutral policy, whereas if control were returned to the school system, it could 
not alter the judicial treatment of a school system's affirmative efforts to desegregate (points [D] and $[\mathrm{H}]$ ). Because of Spangler, district courts may not require school districts to take affirmative steps to desegregate unitary Green areas. ${ }^{147}$ Prophylactic supervision would permit—but could not require-such remedial steps.

Prophylactic supervision would prevent nonunitary school districts from enacting policies that, although not motivated by discriminatory intent, have segregatory effects. Consider a school district (such as DCSS) that has successfully desegregated with respect to student assignments, and wishes to redraw its attendance zones (to reduce transportation costs and administrative inconvenience) in a manner that substantially resegregates its school system. If the district court has relinquished control over student assignments as allowed by Freeman, school officials may adjust attendance zones without judicial interference (point [B] on Figure 1). The segregatory effect of the modification is irrelevant so long as the action is not motivated by discrimination. In contrast, if the district court retained prophylactic supervision over unitary Green areas until the school district has achieved unitary status, the district court would reject any proposed modifications that aggravate existing segregation. ${ }^{148}$ Prophylactic supervision would therefore substantially reduce the likelihood of incremental resegregation prior to total compliance. Mandating prophylactic supervision by district courts would have been more faithful to the spirit of Brown, promoting rather than hindering effective desegregation.

One might challenge this concern about incremental resegregation as excessive. Dowell and other cases illustrate that completely desegregated school districts often quickly resegregate after district courts withdraw supervision. ${ }^{149}$ One might argue that the gradual resegregation permitted by Freeman is ultimately inconsequential because in those cases where prophylactic supervision could prevent incremental resegregation, such supervision would merely postpone the inevitable.

There are two responses to this argument. First, the possibility of future resegregation cannot diminish a school district's obligation to comply with the Constitution. The Equal Protection Clause as interpreted by Brown unequivocally requires the desegregation of all unlawfully segregated school districts. Incremental withdrawal, by contrast, allows a school district that has yet to comply with the Fourteenth Amendment to set in motion itself the process of

enact such policies at its discretion. In practice, however, a court would likely approve school district policies that did not affect racial balance within the school system.

147. Pasadena Bd. of Educ. v. Spangler, 427 U.S. 424, 434-37 (1976); see also text accompanying notes 62-65 supra.

148. It is important to note that even if the district court continued to supervise all areas in such cases, it still could not completely prevent resegregation. Freeman is a perfect example. DCSS discharged its affirmative duty to desegregate student assignments soon after court supervision began. Freeman v. Pitts, 112 S. Ct. 1430, 1439 (1992). Nevertheless, student attendance at DCSS schools has subsequently resegregated because of demographic shifts in and around DeKalb County independent of school district policies. Id. at 1447. Moreover, the resegregation occurred despite judicial supervision of student assignments since 1969. Because the resegregation was not the result of actions taken by DCSS, prophylactic supervision could not have prevented it.

149. See text accompanying notes 117-125 supra. 
resegregation..$^{150}$ Such resegregation is fundamentally different from resegregation subsequent to dismissal of the litigation because it undermines efforts to remedy the school district's constitutional violations. ${ }^{151}$ Suggesting that this sort of resegregation is ultimately inconsequential implies that compliance in general is inconsequential. Segregated school districts should not in any way be permitted to evade compliance with the Fourteenth Amendment.

The second response focuses on the practical effects of desegregation. Although disagreement still surrounds the issue, ${ }^{152}$ most research demonstrates that desegregation has a lasting positive impact on the "life chances" of African-American students. ${ }^{153}$ For instance, a recent survey by Christopher Jencks and Susan Mayer indicates that African-American students "learn[] more in predominantly white schools than in predominantly black schools, even with family background controlled." 154 In addition, Professor Liebman notes that desegregation has positive effects "on [the] dropout, teenage pregnancy, and delinquency rates [of black students]; on the likelihood that blacks will attend and succeed at college ... secure employment in predominantly white job settings, and live in integrated neighborhoods as adults; and on the salary levels

150. See text accompanying notes 104-105 supra.

151. See text accompanying notes $126-130$ supra.

152. Some notable African-American scholars remain skeptical about whether school desegregation ultimately benefits blacks. See Derrick Bell, And We Are Not Saved: The Elusive Quest for RACIAL JUSTICE 102-22 (1987) (contending that racial integration is no guarantee of effective education for black children and may in some cases disadvantage them); THOMAs SowELL, Crvil RrGHTs: RHETORIC OR REALTrY? 61-72 (1984) (challenging desegregation's underlying assumption that racial integration is essential to equality of education).

153. See Liebman, supra note 7, at $356-58$ (reviewing studies indicating that integration "improve[s] the 'life chances' of blacks'). For additional literature discussing the positive impact of school desegregation on the "life chances" of affected students, see generally ROBERT L. CRAIN \& JACK Strauss, School Desegregation and Black Occupational Atrainments: Results from a LongTERM EXPERIMENT (1985); Jomills Henry Braddock II, Robert L. Crain \& James M. McPartland, A Long-Term View of School Desegregation: Some Recent Studies of Graduates as Adults, 66 Pri DetTA KAPPAN 259 (1984); Jomills Henry Braddock II \& James M. McPartland, The Social and Academic Consequences of School Desegregation, EQUITY \& CHOICE, Feb. 1988, at 5; Rita E. Mahard \& Robert L. Crain, Research on Minority Achievement in Desegregated Schools, in THE CONSEQUENCES OF SCHOOL Desegregation 103 (Christine H. Rossell \& Willis D. Hawley eds., 1983); Thomas F. Pettigrew, New Patterns of Racism: The Different Worlds of 1984 and 1964, 37 RutGers L. REv. 673 (1985); William L. Taylor, The Crucial Role of Education in Achieving the Civil Rights Goals of the 1980's, 37 RutGers L. REv. 961 (1985). For a less optimistic opinion of desegregation's tangible results, see GeOFFREY R. Stone, louts M. Seidman, Cass R. Sunstein \& Mark V. Tushnet, Constitumonal law 530-31 (2d ed. 1991) (contending that "[w] $w$ hile there is no proof that integration has reduced white achievement levels, neither is there proof that it has aided blacks in any demonstrable fashion").

154. Susan Mayer \& Christopher Jenks, Growing Up in Poor Neighborhoods: How Much Does It Matter?, 243 SCIENCE 1441, 1442-43 (1989). Another commentator has unequivocally concluded:

School desegregation has benefited disadvantaged groups enormously. In the generation since executive branch and court-ordered desegregation plans have significantly desegregated schools, minority student performance in desegregated public schools has improved greatly. Minorities' performances on standardized achievement and intelligence quotient tests have risen in desegregated settings, as have career opportunities of minorities attending desegregated schools.

Eric S. Stein, Note, Attacking School Segregation Root and Branch, 99 YALE L.J. 2003, 2003 (1990) (citations omitted); see also Mahard \& Crain, supra note 153, at 121 ("It seems reasonably clear that minority children who attend desegregated schools perform better on standardized achievement tests than do similar students who attend segregated schools."). 
blacks attain in the labor market."'155 Thus, even if the desegregation of a school district is ultimately ephemeral, it may provide substantial benefits to those students able to attend integrated schools.

Another important benefit of school desegregation is that it can stabilize demographic shifts within a community, thereby stunting residential segregation and its accompanying problems. The Supreme Court has long recognized the interrelation of school segregation and private housing choices. In Keyes v. School District No. 1, the Court stated that racial identifiability of schools "may have a profound reciprocal effect on the racial composition of residential neighborhoods within a metropolitan area." 156 Similarly, in Swann v. Charlotte-Mecklenburg Board of Education, the Court acknowledged that "[p]eople gravitate toward school facilities" and that schools' locations "may thus influence the patterns of residential development of a metropolitan area and have important impact on composition of inner-city neighborhoods." 157 Moreover, researchers have discredited speculation that "desegregation efforts might trigger such a large exodus of white students that racial isolation actually increases." 158 For example, a study by Diana Pierce showed that metropolitanarea school desegregation significantly increased a region's level of residential integration regardless of school district size and geographic region. ${ }^{159}$ As a review of the relevant research concluded, "[t]he right kind of school desegregation plan can slow the process of racial change and encourage residential desegregation." 160 Thus, incremental withdrawal of district court supervision that prevents effective desegregation can foreclose an opportunity to stabilize a community's demographic shifts. As a result, communities may lose forever a chance for complete and lasting integration. ${ }^{161}$

\section{B. The Lingering Question: Under What Conditions May a District Court Reassert Control over Released Areas of Operation?}

The Freeman Court stated that district courts may return control of unitary

155. Liebman, supra note 7, at 356-57 (footnote omitted).

156. Keyes v. School Dist. No. 1, 413 U.S. 189, 202 (1973).

157. Swann v. Charlotte-Mecklenburg Bd. of Educ., 402 U.S. 1, 20-21 (1971).

158. Fints Welch \& Audrey Light, New Evidence on SChool Desegregation 66-67 (1987).

159. Diana Pearce, Breaktng Down Barriers: New Evidence on the Impact of Metropolitan School Desegregation on Housing Patterns (1980).

160. Willis D. Hawley, Robert L. Crain, Christine H. Rossell, Mark A. Smylie, Ricardo R. Fernández, Janet W. Schofield, Rachel Tompkins, William T. Trent \& Maril yn S. Zlotnik, Strategies for EFFective Desegregation: Lessons fRom Research 63 (1983). For an account of how metropolitan-wide desegregation helped to stabilize demographic shifts and promote residential integration in Charlotte, North Carolina, see FrYe GallLard, ThE DREAM Long Deferred 155-59 (1988).

161. Various studies have reached the following conclusions: (1) "the effects of schools on demography might be greater than the impact of demographic changes on schools;" (2) "school districts have considerable power to help shape and maintain housing patterns, either for the purpose of encouraging desegregation, or for the purpose of reinforcing segregation in both schools and housing;" and (3) "extensive court-ordered plans may actually foster demographic stability," as evidenced by the fact that "[l] ong lasting desegregation has been achieved in many districts." Brief of the NAACP, DeKalb County, Georgia, Branch of the NAACP et al., as Amici Curiae in Support of Respondents app. at 3-5, Freeman v. Pitts, 112 S. Ct. 1430 (1992) (No. 89-1290). 
Green areas to local authorities and limit judicial supervision to Green areas still segregated. ${ }^{162}$ But Freeman did not define the conditions under which a district court may regain control over such areas once they have been returned to local control. ${ }^{163}$

One possible standard is that articulated in Board of Education v. Dowell. In Dowell, the Court stated that, once a school district achieves total compliance and the district court dissolves its desegregation order, the district court may reassert control over the system only upon proof of an independent constitutional violation. ${ }^{164}$ Absent evidence that resegregation is traceable to new instances of purposeful discrimination by school officials, district courts cannot reestablish jurisdiction regardless of the degree to which the system resegregates. ${ }^{165}$

The problem with the Dowell standard is that it is often insuperable, not only because resegregation is most frequently attributable to nondiscriminatory action, but also because of the practical difficulties in proving purposeful discrimination. ${ }^{166}$ Such a stringent standard seems inappropriate in cases of partial compliance such as Freeman. Instead, the standard should be that of "reasonable necessity": Courts should reassert control over a previously released Green area upon a showing that judicial supervision of that area is "reasonably necessary" to the school district's achievement of unitary status.

Under a reasonable necessity standard, plaintiffs could prevent school officials from enacting policies that would resegregate released areas. Consider again a partially compliant school district that has achieved unitary status with respect to student assignments. If the school district altered its attendance zones in a way that aggravated racial imbalance and impeded the desegregation of areas still unlawfully segregated, plaintiffs could petition the district court to reassert control over student assignments. If the court found that the prevention of resegregation in student assignments was "reasonably necessary" to the school system's complete desegregation, the court could reestablish its supervision over this area. Thereafter, the court could screen all proposed modifica-

162. Freeman v. Pitts, 112 S. Ct. $1430,1445-46$ (1992).

163. In his concurrence, Justice Souter stated that since "the district court retains jurisdiction over the case, it should . . . reassert control over student assignment[ ]" if it determines that "the vestige of discrimination in one factor will act as an incubation for resegregation [in student assignments]." Id. at 1455 (Souter, J., concurring). Justice Souter, however, did not address the problem of resegregation caused by actions of the school district. See notes 107-111 supra and accompanying text.

164. Board of Educ. v. Dowell, 111 S. Ct. 630, 638 (1991). As the Court stated in United States v. Fordice, 112 S. Ct. 2727 (1992), "if challenged policies are not rooted in the prior dual system, the question becomes whether the fact of racial separation establishes a new violation of the Fourteenth Amendment under traditional principles." Id. at 2737 n.6.

165. See notes 6-7 supra and accompanying text.

166. As one commentator recently noted,

proving discriminatory intent by school boards has become increasingly difficult as school boards today are far more likely to mask discriminatory motives than in the past. Unlike twenty-five years ago when many school boards openly segregated schools, current government actors veil their intent by avoiding the creation of a "paper trail" that would facilitate findings of discrimination.

Stein, supra note 154, at 2004 (citations omitted). As Stein points out, plaintiffs have failed to establish liability in several recent desegregation cases for precisely this reason. See id. at 2004 n.11. 
tions to student assignment policy to ensure that any changes would not hinder efforts to remedy lingering segregation. Although the school district would be under no obligation to take affirmative steps to desegregate with respect to student assignment, reestablished judicial supervision could inhibit local authorities' ability to take actions leading to rapid resegregation. ${ }^{167}$

While the adoption of a reasonable necessity standard would make incremental resegregation less likely, it would be much less effective than prophylactic supervision by district courts. ${ }^{168}$ Prophylactic supervision would prevent all modifications to school policies that have segregatory effects; a reasonable necessity standard could only prevent such modifications where such resegregation is likely to impede the school district's progress toward unitary status. Nevertheless, a standard of reasonable necessity could mitigate the potentially detrimental effects of incremental withdrawal on effective desegregation.

\section{Conclusion}

More than thirty-eight years have passed since the Supreme Court decided Brown v. Board of Education, yet today America's public schools are still largely separate and unequal. ${ }^{169}$ In each desegregation case, a court must balance several competing objectives. In Freeman, the Court focused on the particular importance of one of these objectives, namely returning elementary and secondary schools to community control. ${ }^{170}$ While local autonomy in the field of public education is indeed important, it should not be emphasized at the expense of the other "ultimate objective": the effective desegregation of previously segregated school districts. ${ }^{171}$ The Court could have decided Freeman

167. Note that once the district court reasserts control over a Green area, its task is the same as prophylactic supervision. See text accompanying note 148 supra.

168. See text accompanying note 148 supra.

169. According to the United States Department of Education, 9 of the country's 10 largest school districts, including New York, Los Angeles, Chicago, Miami, Philadelphia, Detroit, Houston, and Dallas, had white enrollments of less than 27\% in 1984. Center for Educational Statistics, U.S. Department of Education, The Condition of Education 179, tbl. 1:27-1 (Joyce B. Stem ed., 1987); see also Committee on the Status of Black Americans, National Research Counct, A ComMON Destiny: Blacks and AMERICAN SOCIETY 379 (Gerald David Jaynes \& Robin M. Williams, Jr. eds., 1989) (concluding that "[s]egregation and differential treatment of blacks continue to be widespread in schools"); STONE ET AL., supra note 153, at 530 (noting that recent data indicates that "about a third of black students nationwide attended schools with virtually all-black enrollments and over 63 percent attended schools that were at least 50 percent black"); Brown, supra note 4, at 1106 (stating that "[o]ver thirty-five years [after Brown $I]$... de jure segregation of public school students has been replaced by de facto segregation in many areas of the country") (footnotes omitted); Shaw, supra note 112 , at 60 (concluding that we are entering the next century "with a legacy of separate and unequal schools"); Tatel, supra note 18, at 62 (noting that "18 of the 45 largest central city school districts in the country are 70 percent or more minority"). For vivid descriptions of the inequality of educational opportunity for students attending inner-city schools with predominantly minority student bodies, see Alex Kotlowtrz, There Are No Children Here: The Story of Two Boys Groweng Up in the Other America (1991), and Jonathan Kozol, Savage Inequalities: ChIIdren in America's Schools (1991).

170. See notes 56-59 supra and accompanying text.

171. Justice Marshall dissented for precisely this reason in Dowell v. Board of Education, 498 U.S. 237 (1991). He felt that the majority"s decision "risks subordination of the constitutional rights of Afro-American children to the interest of school board autonomy," and that while "the courts must consider the value of local control, ... that factor primarily relates to the feasibility of a remedial 
differently, consistent with its precedent, in a manner that would have promoted, rather than hindered, effective desegregation. But in its haste to return control over school systems to local authorities, the Court seems to have forgotten one of its most enduring messages, that "separate educational facilities are inherently unequal." 172 As the late Justice Thurgood Marshall warned: "Our nation, I fear, will be ill served by the Court's refusal to remedy separate and unequal education, for unless our children begin to learn together, there is little hope that our people will ever learn to live together."'173

measure . . . not whether the constitutional violation has been remedied." Id. at 267 (Marshall, J., dissenting) (footnote and citation omitted).

172. Brown v. Board of Educ., 347 U.S. 495 (1954) (Brown I).

173. Milliken v. Bradley, 418 U.S. 717, 783 (1974) (Marshall, J., dissenting) (Milliken I). 